\title{
A Study on the Effects of Live Commerce and Influencer Characteristics on Purchase Intention: Focusing on Perceived Value and Self-consistency
}

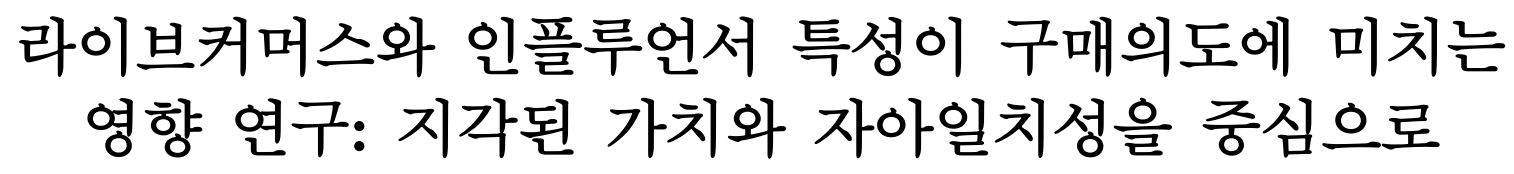

Jin Hwa Roh ${ }^{1}$

노진화 $^{1}$

${ }^{1}$ Ph.D, Interactive Contents \& Cognitive Semiotics LAB, InHa University, Korea, realrojina@gmail.com

\begin{abstract}
This study is aimed to examine the mediating effects of perceived value and the moderating effects of self-consistency, with respect to the effects of the characteristics of live commerce and characteristics of influencer on purchase intention. Based on prior research reviews, a research model was established, and a survey was conducted on 303 live commerce users and verified. As a result of the analysis, First, the practical value was affected in the order of the live commerce's information, entertainment, and economics, and the hedonistic value was significantly affected in the order of entertainment, economics, and information. Practical value was affected in the order of the influencer's expertise, interactivity, reliability, and attractiveness, and statistically significant result was shown on the hedonistic value in the order of interactivity, reliability, and attractiveness. Second, as a result of verifying the mediating effect of perceived values, live commerce's information and economics were fully mediated in practical values, and entertainment was partially mediated. Entertainment and economics were fully mediated in hedonistic values, and information was partially mediated. Influencer's professionalism, attractiveness, reliability, and interaction were partially mediated in both practical and hedonistic values. Third, in the effect of self-consistency control, the actual self was found to be controlling the relationship between economics and professionalism, and the hedonistic self was controlling information and attractiveness. This study is intended to present the impact of perceived consumption value and self-consistency on consumers' purchase intentions after COVID-19, and based on this, the implications for practitioners who are considering strategies to gain competitiveness in the live commerce market were suggested.
\end{abstract}

Keywords: Live Commerce, Influencer, Perceived Value, Self-consistency, Purchase Intent, Consumer Preferences

요약: 본 연구는 라이브커머스의 특성과 인플루언서의 특성이 구매의도에 미치는 영향에 관 하여, 지각된 가치의 매개효과와, 자아일치성의 조절효과를 연구하고자 했다. 선행연구 고찰

Received: June 11, 2021; 1st Review Result: July 27, 2021; 2nd Review Result: September 12, 2021 Accepted: October 31, 2021

*본 연구는 노진화의 인하대학교 인터랙티브콘텐츠 박사학위 논문 '라이브커머스의 구매의도에 대한 현대 소비 기호학적 분석에 관한 연구’ 의 양적 연구를 요약하였습니다. 
을 바탕으로 연구모형을 수립하고, 라이브커머스 이용자 303명을 대상으로 설문조사를 실시 하여 검증하였다. 결과 첫째, 라이브커머스는 정보성, 오락성, 경제성순으로 실용적 가치에 영 향을 주었고, 오락성, 경제성, 정보성순으로 쾌락적 가치에 유의미한 영향을 미쳤다. 인플루언 서는 전문성, 상호작용성, 신뢰성, 매력성 순으로 실용적 가치에 영향을 주었고, 상호작용성, 신뢰성, 매력성순으로 쾌락적 가치에 통계적으로 유의미한 결과를 나타냈다. 둘째, 지각된 가 치의 매개효과를 검증한 결과, 라이브커머스 정보성, 경제성은 실용적 가치에 완전매개했고, 오락성은 부분매개했다. 오락성, 경제성은 쾌락적 가치를 완전매개했고, 정보성은 부분매개했 다. 인플루언서 전문성, 매력성, 신뢰성, 상호작용성은 실용적 가치와 쾌락적 가치를 모두 부 분매개했다. 셋째, 자아일치성 조절효과에서, 실제적 자아는 경제성과 전문성이 구매의도 관 계를 조절하고 있었으며, 쾌락적 자아는 정보성과 매력성이 조절하고 있었다. 본 연구는 COVID-19 이후 소비자들의 구매의도에 대해 지각된 소비가치와 자아일치성이 각 특성간 미 치는 영향을 구체적으로 제시했다는 점에서 학문적 의의가 있으며, 이를 토대로 라이브커머 스 시장에서 경쟁력을 확보하기 위해 전략을 고민하는 실무자들에게 시사점을 제시하고자 한다.

핵심어: 라이브커머스, 인플루언서, 지각된 가치, 자아일치성, 구매의도, 소비가치

\section{1. 서론}

\section{1 연구배경 및 목적}

최근 코로나 팬데믹 이후 언택트 문화 확산은 ‘라이브커머스'라는 새로운 플랫폼 지형을 만들어 내고 있다. 라이브커머스 $\mathrm{AR} \cdot \mathrm{VR}$ 등의 실감형 콘텐트 기술은 실시간 상호작용을 통해 제품에 대한 보다 구체적인 정보를 제공하여 소비 불확실성을 줄이고 있다[1]. 이는 세분화된 개인의 취향과 니즈를 충족시킬 뿐만 아니라, 쇼핑 프로세스를 향상시킨다. 국내 라이브커머스 거래량은 2023년 약 10조 원을 전망하고 있다[2]. 라이브커머스와 인플루언서의 특성은 구매의도에 중요한 요인이 되고있다. 구매의도와 관련한 선행연구들을 조사해 보면 지각된 가치(실용적 가치, 쾌락적 가치)는 구매의도와 추천의도에 영향을 미치는 중요한 변수가 되고 있다[3]. 인플루언서와의 자아일치성(실제적 자아, 이상적 자아)도 구매의도에 중요한 요인이 되고 있었다. 소비자는 자이이미지와 브랜드 이미지 간에 일치성이 높을 때 긍정적인 소비감정을 느끼고, 해당 브랜드에 대한 구매의도 및 구전효과에도 긍정적인 영향을 미친다[4]. 따라서 본 연구는 선행연구를 바탕으로 라이브커머스 특성과 인플루언서 특성이 구매의도에 미치는 관계에서 지각된 가치의 매개성과 자아일치성의 조절성을 고려하여 본 연구를 살펴보고자 한다. 향후 기업이 포스트 코로나 시대의 소비자 니즈를 이해하고, 새로운 고객경험 가치의 시사점을 제공하고자 한다.

\section{2 연구범위 및 방법}

본 연구의 목적을 수행하기 위해 라이브커머스 국내외 선행연구와 가설을 실증적으로 고찰하였다. 이론적 부분은 홈쇼핑 및 이커머스 특성과 시장현황, 인플루언서에 대한 개념을 참고하여 구매에 영향을 미치는 주요 요인을 도출하였다. 자료수집을 위해 
네이버 쇼핑라이브이용자를 대상으로 설문지 총 303부를 수집하였다. 자료의 통계처리는 데이터 코딩과 데이터 크리닝 과정을 거쳐, SPSS v. 21.0 통계 패키지 프로그램으로 분석하였고, 조사대상자의 인구사회학적 현황은 빈도분석을 실시하였다. 측정 도구에 대한 타당성을 검증하기 위하여 요인분석(factor analysis)과, 신뢰도를 검증을 위한 Cronbach's $\alpha$ 계수를 산출하였다. 주요 변수의 정규성 검증을 위하여 기술통계 분석(descriptive statistics analysis)을 실시하였고, 각 변수 간 상관관계를 알아보기 위하여 pearson의 상관관계 분석(correlation analysis)을 실시하였다. 연구모형에 따른 가설의 검증을 위하여 다중회귀분석(multiple regression analysis)을 실시하였다. 또한, 지각된 가치의 매개효과를 알아보기 위하여 3 단계 매개회귀분석을 실시하였고, 자아일치성의 조절효과를 알아보기 위하여 위계적 회귀분석(hierarchical analysis)을 실시하였다.

\section{2. 이론적 배경}

\section{1 라이브커머스 개념 및 특성}

라이브커머스는 라이브 스트리밍과 이커머스의 합성어이다. 기존 이커머스는 제품을 실제 경험하지 못한 상황에서 구매 의사결정을 해야하는 시스템이었다[5]. 때문에 브랜드 신뢰와 구매에 대한 지각된 위험 수준의 문제점이 제기되어왔다[6]. 반면, 라이브커머스는 실시간 방송을 통해 실재감, 현장감을 재현하고 상호작용을 통해 자세한 정보를 제공함으로써 문제와 해결을 즉시 해소할 수 있다는 장점이 있다. 이는 소비자의 구매 여정을 줄이게 할 뿐만 아니라 지각된 위험수준을 낮추게 한다. 라이브커머스의 가장 큰 특징인 양질의 정보성은 소비자의 지적 호기심을 충족시키고, 소비자는 생방송을 통한 유쾌함과 즐거움을 극대화하여, 구매만족 및 브랜드 애착도를 향상시킬 수 있다[7]. 또한, 라이브커머스에서 상품가격 및 할인, 이벤트 정도도 이용자 태도에 영향을 줄 수 있다[8]. 따라서 본 연구는 라이브커머스 특성을 정보성, 정보성. 오락성. 경제성으로 정의하였다.

\section{2 인플루언서의 개념 및 특성}

인플루언서는 팔로워십을 형성하고 사회에 영향력을 미치는 개인이다. 라이브커머스에서 인플루언서는 소비자와의 접점에서 인터랙티브한 소비 경험을 강화시키고, 제품에 대한 궁금증을 실시간으로 해결할 뿐만 아니라, 합리적 소비가치를 제안한다[9]. 인플루언서는 소비자에게 제품과 브랜드에 대한 선호도를 높이는 역할을 한다. 인플루언서 특성 중 매력성은 마음을 사로잡는 힘이다. 이는 정보원이나 광고모델에 대해 갖게 되는 광고 및 브랜드에 대한 호의적인 태도를 형성하고, 소비자의 구매의도에 긍정적인 영향을 미친다[3]. 전문성은 기술 지식 혹은 능력으로 소비자 판단의 준거가 된다. 신뢰성은 믿을 수 있다고 받아들이는 정도의 정의로써 광고태도와 구매의도에 영향을 미칠 수 있다[10]. 상호작용성은 커뮤니케이션 개념으로 사회적 실재감과 몰입, 구매의도에 유의한 영향을 미친다. 따라서 본 연구에서 인플루언서 특성으로 나타나는 전문성, 정보 유용성, 상호작용성은 구매의도에 유의한 영향을 미친다고 가정하였다.

\section{3 지각된 가치}


지각된 가치란 서비스에 대한 편익의 내적 기준으로, 구매의도에 긍정적인 영향을 미치며 고객 만족도와 지속 의도에도 영향을 미친다[11]. 지각된 가치는 브래드 유통단계를 줄여 소비자의 경험에 직간접적으로 다가간다. 지각된 가치에 영향을 미치는 중요한 요인으로 실용적 가치는, 부정적 위험을 감소시키고 소비자들의 편의성과 사용성, 유용성, 비용을 포함한 정보 등을 제공함으로써 의사결정을 충족시킨다[12]. 쾌락적 가치는 인플루언서의 물리적 매력, 신체적 매력뿐만 아니라 할인, 재미, 오락 및 감각적 자극과 대인관계 등을 통해 구매의도에 영향을 미친다[13]. 본 연구는 선행연구를 바탕으로 지각된 가치의 실용적, 쾌락적 특성이 라이브커머스의 특성과 인플루어서의 특성 간 구매의도를 조절할 것이라고 가정하였다.

\section{4 자아일치성}

자아일치성은 소비자의 주관적 해석에 따른 자아 이미지와 제품의 개성 또는 서비스 간의 일치 정도이다[4]. 소비자는 자신의 취향이나 상징적 이미지를 표현하는 욕구를 가지고 있으며, 소비를 통해 자신의 정체성을 구별하고, 가치관과 철학을 투영시킨다. 또한, 자아 이미지와 제품의 이미지를 비교하는 경향이 있으며, 비교 과정에서 제품의 속성이 자신의 이미지와 조화를 이룰 때 그 제품을 구매할 가능성이 크다[14]. 자아일치성의 특성인 실제적 자아는 자기 자신이 인식하고 있는 현재 자신의 모습이며, 이상적 자아는 한 개인이 되고 싶어 하는 자아이다[15]. 본 연구는 자아일치성이 조절변인으로 소비자들의 구매의도를 조절한다고 예측하였다.

\section{5 구매의도}

구매의도는 사회, 문화적 준거집단의 동질성과 개인적, 심리적 요인 등에 의해서 소비자들의 기호와 요구가 구매행동으로 전환되는 것을 의미한다[16]. 소비 기호는 계층간 시스템 속에서 비슷한 가치관과 규범의 영향을 받아 인지적이고 감정적인 정보처리를 통해 서비스나 상품에 대한 태도의 원인이 된다[17]. 본 연구에서 구매의도에 미치는 영향요인들에 대한 선행연구를 검토한 결과, 다양한 원인이 제시되고 있으나, 라이브커머스라는 연구 대상에 적합한 원인으로는 크게 라이브커머스의 특성과 인플루언서의 특성 그리고 지각된 가치, 자아일치성으로 구분하여 살펴볼 수 있다고 판단하였다. 따라서 라이브커머스와 구매의도 간, 인플루언서와 구매의도 간, 지각된 가치와 구매의도 간, 자아일치성과 구매의도 간 선행연구를 검증하였고, 이러한 특성이 구매의도에 미치는 영향을 연구하고자 했다.

\section{3. 연구방법}

\section{1 연구모형 및 가설}

본 연구의 목적은 라이브커머스 특성과 인플루언서의 특성이 구매의도에 미치는 영향과의 관계에서 지각된 가치를 매개효과로, 자아일치성을 조절효과로 규명하는 것이다. 주요 변수의 정규성 검증을 위하여 기술통계 분석을 실시하였고, 각 변수간 상관관계를 알아보기 위하여 pearson의 상관관계 분석과 다중회귀분석을 실시하였다. 또한, 지각된 가치의 매개효과를 알아보기 위하여 3 단계 매개회귀분석을 실시하였다. 
자아일치성의 조절효과를 알아보기 위하여 위계적 회귀분석을 실시하였다. 본 연구는 선행연구 조사내용을 바탕으로 [그림 1]과 같은 연구모형을 도식화하였다.

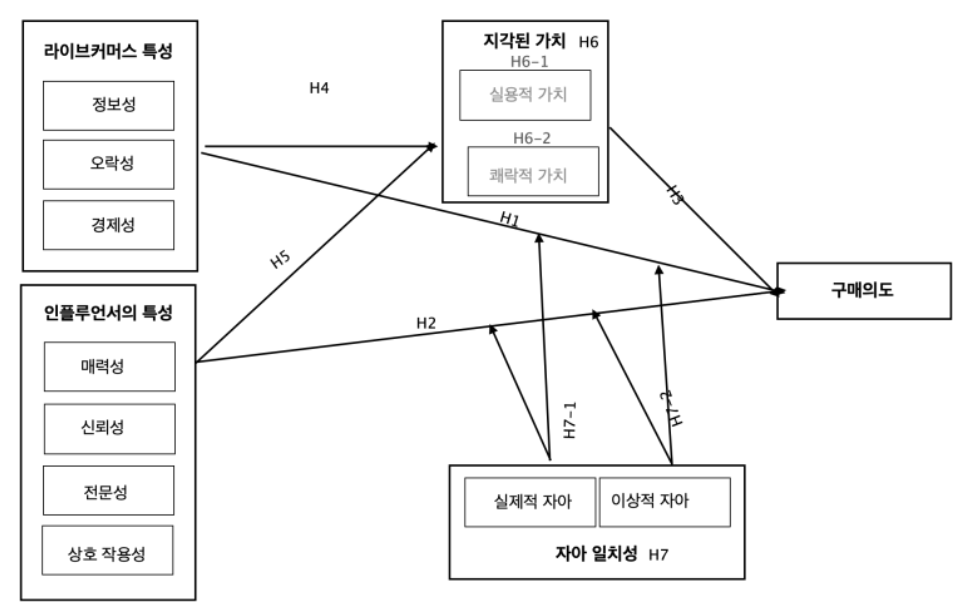

[그림 1] 연구모형

[Fig. 1] Research Mode

가설 1. 라이브커머스 특성은 구매의도에 영향을 미칠 것이다.

가설 2. 인플루언서 특성은 구매의도에 영향을 미칠 것이다.

가설 3. 지각된 가치는 구매의도에 영향을 미칠 것이다.

가설 4. 라이브커머스 특성은 지각된 가치에 영향을 미칠 것이다.

가설 5. 인플루언서 특성은 지각된 가치에 영향을 미칠 것이다.

가설 6. 지각된 가치는 구매의도 간의 매개효과가 나타날 것이다.

6-1: 지각된 가치는 라이브커머스 특성과 구매의도를 매개할 것이다.

6-2: 지각된 가치는 인플루언서 특성과 구매의도를 매개할 것이다.

가설 7. 자아일치성은 라이브커머스, 인플루언서 특성 간 구매의도를 조절할 것이다.

7-1: 자아일치성은 라이브커머스 특성과 구매의도를 조절할 것이다.

7-2: 자아일치성은 인플루언서 특성과 구매의도를 조절할 것이다.

\section{2 자료의 수집}

본 연구의 대상은 지난 1 년간 라이브커머스를 시청하거나 구매 경험이 있는 일반인을 대상으로 온라인 설문조사법을 통하여 2021년 3월 26일부터 2021년 4월 1일까지 약 1 주일간 실시하였으며 설문지는 총 320 부가 회수되었다. 불확실한 응답을 제외한 303 부 응답자 표본을 추출하여 인구통계학 요소는 성별, 나이, 교육 수준을 포함하며 응답자가 라이브커머스에 관한 총 66 개 설문 문항을 설정하였다. 결과, 응답자의 성별은 여자 167 명(55.1\%), 남자 136명(44.9\%)으로 나타났고, 연령은 30세 이하 63명(20.8\%), 31-40세 71명(23.4\%), 41 50세 103명(34.0\%) 순으로 나타났다. 소득수준은 200-400만 원 미만 120 명(39.6\%), 400-800만 원 미만 74명(24.4\%)이 높게 나타났다. 라이브커머스 시청빈도는 월 1 2회 240명(79.2\%), 월 3 4회 36명(11.9\%) 순으로 나타났고, 시청시간은 30분 이하 248명(81.8\%), 30분-1시간 49명(16.2\%) 순으로 나타났다. 시청 시간대는 저녁 6-10시 123 명(40.6\%), 밤10시 이후 118 명(38.9\%)가 높게 나타났으며, 구매한 상품은 패션 
126명(41.6\%), 푸드 80명(25.7\%), 라이프 43명(14.2\%), 테크레져 21명(6.9\%), 키즈 19명(6.3\%), 뷰티 16명(5.3\%) 순으로 조사되었다. 구매비용은 1-5만 원 171명(56.4\%), 610 만 원 91 명 $(30.0 \%)$ 순으로 조사되었다.

\section{3 변수의 측정}

종속변수인 구매의도는 박종렬(2014) 등의 선행연구를 바탕으로 라이브커머스 특성과, 인플루언서의 특성으로 나누어 각 4개 문항으로 측정하였다. 독립변수인 라이브커머스 특성은 문동현(2003)의 연구를 근거하였고, 인플루언서의 특성은 서용구(2014) 등의 선행연구를 바탕으로 11 개 문항으로 구성하였으며, 모든 항목은 리커트(Liker) 5 점 척도를 이용하였다. 매개변수인 지각된 가치는 오정엽(2008) 등의 선행연구를 바탕으로 본 연구에 맞게 보완하여 쾌락적 쇼핑가치에 관한 7 개의 문항으로 구성하였다. 조절변수인 자아일치성은 안광호 외(2018) 선행연구를 참조하여 실제적 자아 4개 문항과, 이상적 자아 4 개 문항으로 구성하였다.

\section{4. 연구결과}

\section{1 변수의 신뢰성 및 타당성, 기술통계 및 상관관계 검증}

본 연구에서 변수의 타당성을 분석하기 위해 탐색적 요인분석(exploratory factor analysis)을 사용하였다. 요인분석 방법은 주성분 분석을 사용하였고, 요인회전 요인방식은 요인간의 독립을 가정한 Varimax에 의한 회전, 고윳값 1 이상을 기본으로 요인분석을 실시하였다. 독립변수 요인의 적채치는 0.40 이상으로 나타나 타당성이 검증된 것으로 판단하였으며[18], 신뢰도는 0.60 이상으로 나타나 문제가 없는 것으로 나타났다. 일반적으로 Cronbach's $\alpha$ 계수가 0.60 이상이면 신뢰도에는 문제가 없다고 해석하고 0.70 이상이면 좋다고 해석한다[19]. 변인들의 정규성 가정을 검토한 결과, 왜도와 첨도의 절대값이 각각 3 과 7 을 넘지 않아 정규성 가정을 충족하였고, 상관관계 분석결과 통계적으로 유의미한 정 $(+)$ 의 상관관계 $(\mathrm{p}<.001)$ 가 있는 것으로 나타났다. 측정도구의 신뢰도 및 타당도 분석과 척도화를 위한 요인분석 및 Cronbach's $\alpha$ 값은 다음과 같다.

[표 1] 타당성 및 신뢰도 검증

[Table 1] Validity and Reliability Verification

\begin{tabular}{|c|c|c|c|c|c|c|}
\hline \multirow{11}{*}{$\begin{array}{c}\text { 라이브커머스 } \\
\text { 특성 }\end{array}$} & 요인 & 변수명 & $\mathrm{F} 1$ & Eigen value & Total dispersion & Cronbach's $\alpha$ \\
\hline & \multirow{4}{*}{ 경제성 } & 2 & .877 & \multirow{4}{*}{3.141} & \multirow{4}{*}{26.179} & \multirow{4}{*}{.897} \\
\hline & & 1 & .840 & & & \\
\hline & & 4 & .822 & & & \\
\hline & & 3 & .795 & & & \\
\hline & \multirow{4}{*}{ 정보성 } & 2 & .842 & \multirow[b]{6}{*}{2.535} & \multirow{4}{*}{23.170} & \multirow{4}{*}{.835} \\
\hline & & 3 & .828 & & & \\
\hline & & 1 & .765 & & & \\
\hline & & 4 & .680 & & & \\
\hline & \multirow{2}{*}{ 오락성 } & 3 & .854 & & \multirow{2}{*}{21.127} & \multirow{2}{*}{.818} \\
\hline & & 1 & .796 & & & \\
\hline
\end{tabular}




\begin{tabular}{|c|c|c|c|c|c|c|}
\hline & & 4 & .663 & & & \\
\hline & & 2 & .662 & & & \\
\hline & & & 측도= & *, 총 난 & 석계수 $=7$ & \\
\hline \multirow{15}{*}{$\begin{array}{c}\text { 인플루언서 } \\
\text { 특성 }\end{array}$} & \multirow{5}{*}{$\begin{array}{l}\text { 상호 } \\
\text { 작용성 }\end{array}$} & 2 & .867 & \multirow{5}{*}{3.329} & \multirow{5}{*}{23.781} & \multirow{5}{*}{.883} \\
\hline & & 1 & .834 & & & \\
\hline & & 3 & .814 & & & \\
\hline & & 4 & .735 & & & \\
\hline & & 5 & .549 & & & \\
\hline & \multirow{3}{*}{ 전문성 } & 2 & .850 & \multirow{3}{*}{2.542} & \multirow{3}{*}{18159} & \multirow{3}{*}{.884} \\
\hline & & 3 & .809 & & & \\
\hline & & 1 & .799 & & & \\
\hline & \multirow{3}{*}{ 신뢰성 } & 1 & .847 & \multirow{3}{*}{2.378} & \multirow{3}{*}{16.988} & \multirow{3}{*}{.842} \\
\hline & & 2 & .797 & & & \\
\hline & & 3 & .698 & & & \\
\hline & \multirow{3}{*}{ 매력성 } & 3 & .806 & \multirow{3}{*}{2.188} & \multirow{3}{*}{15.632} & \multirow{3}{*}{.720} \\
\hline & & 1 & .766 & & & \\
\hline & & 2 & .717 & & & \\
\hline & \multicolumn{6}{|c|}{$\mathrm{KMO}=0.898$, 측도 $=0.000, \mathrm{p}<.01^{* *}$, 총 분산설명 누적계수 $=77.560$} \\
\hline \multirow{15}{*}{ 지각된 가치 } & \multirow{7}{*}{$\begin{array}{l}\text { 쾌락적 } \\
\text { 가치 }\end{array}$} & 7 & .797 & \multirow{7}{*}{4.818} & \multirow{7}{*}{34.417} & \multirow{7}{*}{.921 . } \\
\hline & & 6 & .788 & & & \\
\hline & & 2 & .782 & & & \\
\hline & & 4 & .773 & & & \\
\hline & & 1 & .768 & & & \\
\hline & & 3 & .749 & & & \\
\hline & & 5 & .714 & & & \\
\hline & & 5 & .836 & & & \\
\hline & & 6 & .765 & & & \\
\hline & & 3 & .754 & & & \\
\hline & $\begin{array}{l}\text { 실푱석 } \\
\text { 가치 }\end{array}$ & 4 & .753 & 4.599 & 32.853 & .908 \\
\hline & & 2 & .736 & & & \\
\hline & & 7 & .701 & & & \\
\hline & & 1 & .662 & & & \\
\hline & & & 측도 $=($ & , 총 분 & 계수 $=67$ & \\
\hline & & 2 & .878 & & & \\
\hline & 이상적 & 3 & .871 & 3440 & 12000 & 042 \\
\hline & 자아 & 4 & .849 & 3.440 & 42.999 & .943 \\
\hline & & 1 & .843 & & & \\
\hline 자아일치성 & & 1 & .892 & & & \\
\hline & 실제적 & 2 & .867 & 3430 & (12000 & 047 \\
\hline & 자아 & 3 & .859 & 5.439 & 42.990 & .941 \\
\hline & & 4 & .834 & & & \\
\hline & & & 측도= & *, 총 닌 & ㅓㅓㄱ계수 $=8$ & \\
\hline & & 8 & .872 & & & \\
\hline 구매 & & 4 & .855 & 5.309 & 66.367 & .925 \\
\hline & & 5 & .851 & & & \\
\hline
\end{tabular}




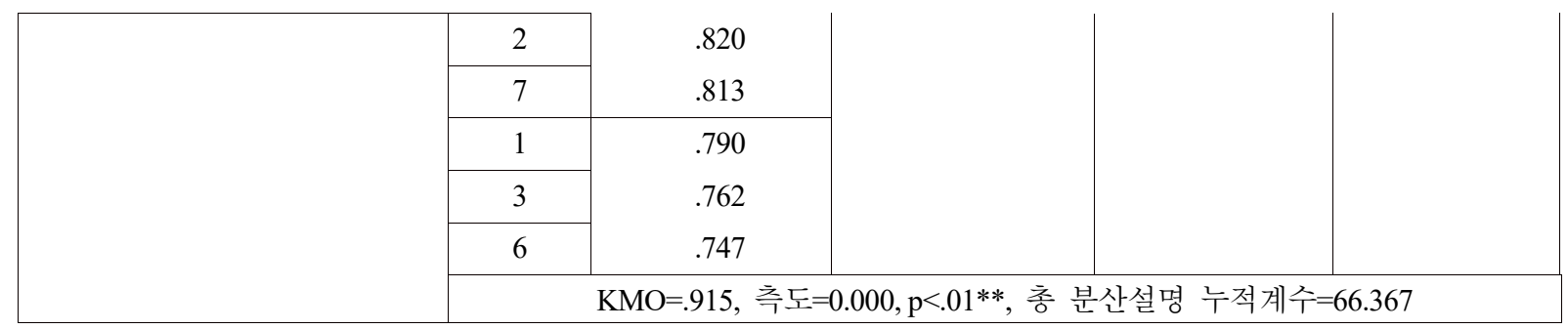

\section{2 가설검증}

\subsection{1 라이브커머스 특성, 인플루언서 특성과 구매의도와 관계}

라이브커머스 특성이 구매의도에 미치는 영향을 검증하기 위하여 다중회귀분석 결과, 회귀모형의 설명력은 $27.8 \%$ 이고, 회귀식은 통계적으로 유의한 것으로 분석되었다 $(\mathrm{F}=38.436, \mathrm{p}<.001)$. 독립 변인들 간의 다중공선성을 확인한 결과 공차한계는 0.10 보다 크게 나타났고, $\mathrm{VIF}$ 는 10 보다 작게 나타나 다중 공선성이 존재할 가능성이 낮은 것으로 볼 수 있다. 독립변수별로는 오락성 $(\beta=.326, \mathrm{p}<.000)$, 정보성 $(\beta=.175, \mathrm{p}<.003)$, 경제성 $(\beta=.137, \mathrm{p}<.021)$ 이 구매의도에 통계적으로 유의미한 정 $(+)$ 의 영향을 미치는 것으로 나타났다. 인플루언서 특성이 구매의도에 미치는 영향을 검증한 결과, 신뢰성 $(\beta=.192$, $\mathrm{p}<.004)$, 상호작용성 $(\beta=.152, \mathrm{p}<.018)$, 매력성 $(\beta=.143, \mathrm{p}<.020)$, 전문성 $(\beta=.139, \mathrm{p}<.035)$ 이 통계적으로 유의미한 정 $(+)$ 의 영향을 미치는 것으로 나타났다.

[표 2] 라이브커머스 특성이 구매의도에 미치는 영향

[Table 2] The Effects of Live Commerce Characteristics on Purchase Intention

\begin{tabular}{|c|c|c|c|c|c|c|c|c|}
\hline \multirow{2}{*}{ 종속변수 } & \multirow{2}{*}{ 독립변수 } & \multicolumn{2}{|c|}{ 비표준화 계수 } & \multirow{2}{*}{$\begin{array}{c}\text { 표준화 계수 } \\
\beta\end{array}$} & \multirow{2}{*}{$\mathrm{t}$} & \multirow{2}{*}{$\mathrm{p}$} & \multicolumn{2}{|c|}{ 공선성 통계량 } \\
\hline & & B & S.E & & & & 공차한계 & VIF \\
\hline \multirow{4}{*}{ 구매의도 } & (상수) & 1.194 & .218 & & 5.481 & .000 & & \\
\hline & 오락성 & .311 & .058 & .326 & $5.345^{* * *}$ & .000 & .650 & 1.540 \\
\hline & 정보성 & .187 & .062 & .175 & $3.011 * *$ & .003 & .712 & 1.404 \\
\hline & 경제성 & .145 & .063 & .137 & $2.321 *$ & .021 & .694 & 1.442 \\
\hline \multicolumn{9}{|c|}{$\mathrm{R}^{2}=.278$, Adj. $\mathrm{R}^{2}=.271, \mathrm{~F}=38.436^{* * *}, \mathrm{p}=.000$} \\
\hline \multicolumn{9}{|c|}{$* \mathrm{p}<.05, * * \mathrm{p}<.01, * * * \mathrm{p}<.001$} \\
\hline
\end{tabular}

[표 3] 인플루언서 특성이 구매의도에 미치는 영향

[Table 3] The Effects of Influencer Attributes on Purchase Intention

\begin{tabular}{|c|c|c|c|c|c|c|c|c|}
\hline \multirow{2}{*}{ 종속변수 } & \multirow{2}{*}{ 독립변수 } & \multicolumn{2}{|c|}{ 비표준화 계수 } & \multirow{2}{*}{$\begin{array}{c}\text { 표준화 계수 } \\
\beta\end{array}$} & \multirow{2}{*}{$\mathrm{t}$} & \multirow{2}{*}{$\mathrm{p}$} & \multicolumn{2}{|c|}{ 공선성 통계량 } \\
\hline & & B & S.E & & & & 공차한계 & VIF \\
\hline \multirow{5}{*}{ 구매의도 } & (상수) & 1.180 & .231 & & 5.106 & .000 & & \\
\hline & 신뢰성 & .190 & .066 & .192 & $2.887 * *$ & .004 & .568 & 1.759 \\
\hline & 매력성 & .161 & .069 & .143 & $2.333^{*}$ & .020 & .674 & 1.485 \\
\hline & 상호작용성 & .158 & .066 & .152 & $2.375^{*}$ & .018 & .615 & 1.627 \\
\hline & 전문성 & .130 & .062 & .139 & $2.117^{*}$ & .035 & .584 & 1.713 \\
\hline \multicolumn{9}{|c|}{$\mathrm{R}^{2}=.249$, Adj. $\mathrm{R}^{2}=.239, \mathrm{~F}=24.678^{* * *}, \mathrm{p}=.000$} \\
\hline \multicolumn{9}{|c|}{${ }^{*} \mathrm{p}<.05, * * \mathrm{p}<.01, * * * \mathrm{p}<.001$} \\
\hline
\end{tabular}




\subsection{2 지각된 가치와 구매의도 간 관계}

지각된 가치가 구매의도에 미치는 영향을 검증하기 위하여 다중회귀분석을 실시한 결과, 분석결과 회귀모형의 설명력은 $41.3 \%$ 이고, 회귀식은 통계적으로 유의한 것으로 분석되었다 $(\mathrm{F}=105.355, \mathrm{p}<.000)$. 독립변수 별로는 쾌락적 가치 $(\beta=.365, \mathrm{p}<.000)$, 실용적 가치 $(\beta=.335, \mathrm{p}<.000)$ 가 구매의도에 통계적으로 유의미한 정 $(+)$ 의 영향을 미치는 것으로 나타났다. 유의미한 정 $(+)$ 의 영향을 미치는 것으로 나타났다.

[표 4] 지각된 가치가 구매의도에 미치는 영향

[Table 4] The Effects of Perceived Value on Purchase Intent

\begin{tabular}{|c|c|c|c|c|c|c|c|c|}
\hline \multirow{2}{*}{ 종속변수 } & \multirow{2}{*}{ 독립변수 } & \multicolumn{2}{|c|}{ 비표준화 계수 } & \multirow{2}{*}{$\frac{\text { 표준화 계수 }}{\beta}$} & \multirow{2}{*}{$\mathrm{t}$} & \multirow{2}{*}{$\mathrm{p}$} & \multicolumn{2}{|c|}{ 공선성 통계량 } \\
\hline & & B & S.E & & & & 공차한계 & VIF \\
\hline \multirow{3}{*}{ 구매의도 } & (상수) & 1.064 & .161 & & 6.601 & .000 & & \\
\hline & 실용적 가치 & .357 & .064 & .335 & $5.539 * * *$ & .000 & .536 & 1.867 \\
\hline & 쾌락적 가치 & .356 & .059 & .365 & $6.043 * * *$ & .000 & .536 & 1.867 \\
\hline \multicolumn{9}{|c|}{$\mathrm{R}^{2}=.413$, Adj. $\mathrm{R}^{2}=.409, \mathrm{~F}=105.355^{* * *}, \mathrm{p}=.000$} \\
\hline
\end{tabular}

\subsection{3 라이브커머스 특성과 지각된 가치와의 관계}

라이브커머스 특성이 실용적 가치에 미치는 영향을 검증하기 위하여 다중 회귀분석을 실시한 결과, 정보성 $(\beta=.376, \mathrm{p}<.001), \quad$ 오락성 $(\beta=.320, \mathrm{p}<.001)$, 경제성 $(\beta=.200, \mathrm{p}<.001)$ 이 실용적 가치에 통계적으로 유의미한 정 $(+)$ 의 영향을 미치는 것으로 나타났다. 오락성 $(\beta=.598, \mathrm{p}<.001)$, 경제성 $(\beta=.159, \mathrm{p}<.001)$, 정보성 $(\beta=.136, \mathrm{p}<.01)$ 은 쾌락적 가치에 통계적으로 유의미한 정 $(+)$ 의 영향을 미치는 것으로 나타났다.

[표 5] 라이브커머스 특성이 지각된 가치에 미치는 영향

[Table 5] The Effects of Live Commerce Characteristics on Perceived Value

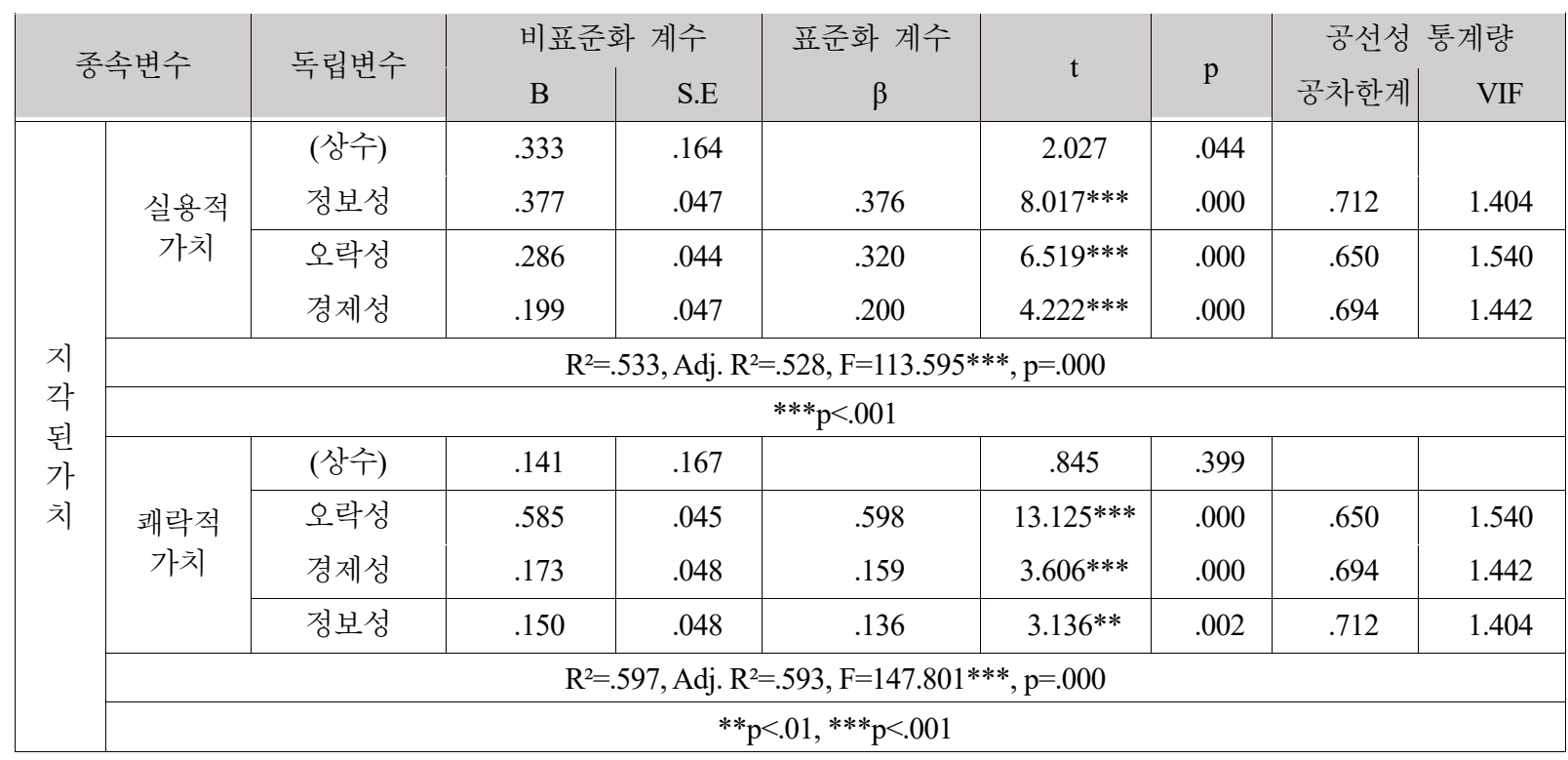




\subsection{4 인플루언서 특성과 지각된 가치와의 관계}

인플루언서 특성이 실용적 가치에 미치는 영향을 검증하기 위하여 다중 회귀분석을 실시한 결과, 전문성 $(\beta=.284, \mathrm{p}<.001)$, 상호작용성 $(\beta=.194, \mathrm{p}<.01)$, 신뢰성 $(\beta=.168, \mathrm{p}<.01)$, 매력성 $(\beta=.117, \mathrm{p}<.05)$ 이 통계적으로 유의미한 정 $(+)$ 의 영향을 미치는 것으로 나타났다. 또한 인플루언서 특성이 쾌락적 가치에 미치는 분석결과, 상호작용성 $(\beta=.278, \mathrm{p}<.001)$, 신뢰성 $(\beta=.219, \mathrm{p}<.001), \quad$ 매력성 $(\beta=.179, \mathrm{p}<.01)$ 이 통계적으로 유의미한 정 $(+)$ 의 영향을 미치는 것으로 나타났다.

[표 6] 인플루언서 특성이 지각된 가치에 미치는 영향

[Table 6] The Effects of Influencer Characteristics on Perceived Value

\begin{tabular}{|c|c|c|c|c|c|c|c|c|c|}
\hline \multirow{2}{*}{\multicolumn{2}{|c|}{ 종속변수 }} & \multirow{3}{*}{$\begin{array}{c}\text { 독립변수 } \\
\text { (상수) }\end{array}$} & \multicolumn{2}{|c|}{ 비표준화 계수 } & \multirow{3}{*}{$\frac{\text { 표준화 계수 }}{\beta}$} & \multirow{3}{*}{$\begin{array}{c}\mathrm{t} \\
4.272 \\
\end{array}$} & \multirow{3}{*}{$\begin{array}{l}\mathrm{p} \\
.000\end{array}$} & \multicolumn{2}{|c|}{ 공선성 통계량 } \\
\hline & & & \multirow{2}{*}{$\begin{array}{c}\mathrm{B} \\
.842\end{array}$} & \multirow{2}{*}{$\begin{array}{l}\text { S.E } \\
.197\end{array}$} & & & & 공차한계 & VIF \\
\hline \multirow{14}{*}{$\begin{array}{l}\text { 지 } \\
\text { 각 } \\
\text { 된 } \\
\text { 가 } \\
\text { 치 }\end{array}$} & \multirow{4}{*}{$\begin{array}{l}\text { 실용적 } \\
\text { 가치 }\end{array}$} & & & & & & & & \\
\hline & & 전문성 & .249 & .053 & .284 & $4.740 * * *$ & .000 & .584 & 1.713 \\
\hline & & 상호작용성 & .188 & .057 & .194 & $3.328^{* *}$ & .001 & .615 & 1.627 \\
\hline & & 신뢰성 & .156 & .056 & .168 & $2.779 * *$ & .006 & .568 & 1.759 \\
\hline & & 매력성 & .124 & .059 & .117 & $2.103^{*}$ & .036 & 674 & 1.485 \\
\hline & \multicolumn{9}{|c|}{$\mathrm{R}^{2}=.378$, Adj. $\mathrm{R}^{2}=.369, \mathrm{~F}=45.207^{* * *}, \mathrm{p}=.000$} \\
\hline & \multicolumn{9}{|c|}{${ }^{*} \mathrm{p}<.05, * * \mathrm{p}<.01, * * * \mathrm{p}<.001$} \\
\hline & \multirow{4}{*}{$\begin{array}{l}\text { 쾌락적 } \\
\text { 가치 }\end{array}$} & (상수) & .422 & .219 & & 1.926 & .055 & & \\
\hline & & 상호작용성 & .296 & .063 & .278 & $4.699 * * *$ & .000 & .615 & 1.627 \\
\hline & & 신뢰성 & .222 & .063 & .219 & $3.551^{* * *}$ & .000 & .568 & 1.759 \\
\hline & & 매력성 & .208 & .066 & .179 & $3.164 * *$ & .002 & 674 & 1.485 \\
\hline & & 전문성 & .064 & .058 & .067 & 1.102 & .271 & .584 & 1.713 \\
\hline & \multicolumn{9}{|c|}{$\mathrm{R}^{2}=.358$, Adj. $\mathrm{R}^{2}=.350, \mathrm{~F}=41.583^{* * *}, \mathrm{p}=.000$} \\
\hline & \multicolumn{9}{|c|}{$* * \mathrm{p}<.01, * * * \mathrm{p}<.001$} \\
\hline
\end{tabular}

\subsection{5 라이브커머스 특성과 구매의도와 관계에서 지각된 가치의 매개효과}

라이브커머스 특성이 구매의도와 관계에서 실용적 가치의 매개효과를 3 단계 회귀 분석한 결과, 1 단계에서 매개 조건을 충족하였고 $(\mathrm{p}<.001), 2$ 단계에서 매개조건을 충족하였다 $(\mathrm{p}<.001) .3$ 단계는 오락성의 회귀계수가 유의하면서 2 단계보다 감소하였다. 정보성, 경제성은 완전매개하였고, 오락성은 부분매개하는 것으로 나타났다. 쾌락적 가치의 매개효과를 분석한 결과 1.2 단계는 실용적 가치와 같이 매개 조건을 충족하였으며, 3 단계에서 오락성, 경제성은 완전 매개하였고, 정보성은 부분 매개하였다.

[표 7] 라이브커머스의 특성과 구매의도 간의 관계에서 실용적 가치의 매개효과

[Table 7] The Intermediate Effect of Practical Value in the Relationship between Live Commerce Characteristics and Purchase Intentions

\begin{tabular}{|c|c|c|c|c|c|c|c|}
\hline 구분 & 단계 & $\beta$ & $\mathrm{t}$ & $\mathrm{p}$ & $\mathrm{F}$ & $\mathrm{R}^{2}$ & 채택유무 \\
\hline \multirow{2}{*}{ 정보성 } & 1 단계 & .620 & $13.712^{* * *}$ & .000 & $188.005^{* * *}$ & .384 & \multirow{2}{*}{ 완전매개 } \\
\cline { 2 - 8 } & 2 2단계 & .395 & $7.461 * * *$ & .000 & $55.670^{* * *}$ & .156 & \\
\hline
\end{tabular}




\begin{tabular}{|c|c|c|c|c|c|c|c|}
\hline & 3단계(독립) & .054 & .898 & .370 & \multirow{2}{*}{$78.252 * * *$} & \multirow{2}{*}{.343} & \\
\hline & 3단계(매개) & .551 & $9.233 * * *$ & .000 & & & \\
\hline \multirow{4}{*}{ 오락성 } & 1단계 & .607 & $13.245^{* * *}$ & .000 & $175.431 * * *$ & .368 & \multirow{4}{*}{ 부분매개 } \\
\hline & 2단계 & .482 & $9.544 * * *$ & .000 & $91.086^{* * *}$ & .232 & \\
\hline & 3단계(독립) & .202 & $3.494 * *$ & .001 & \multirow{2}{*}{$86.907 * * *$} & \multirow{2}{*}{.367} & \\
\hline & 3단계(매개) & .461 & $7.984 * * *$ & .000 & & & \\
\hline \multirow{4}{*}{ 경제성 } & 1단계 & .528 & $10.777^{* * *}$ & .000 & $116.147 * * *$ & .278 & \multirow{4}{*}{ 완전매개 } \\
\hline & 2단계 & .380 & $7.126^{* * *}$ & .000 & $50.780^{* * *}$ & .144 & \\
\hline & 3단계(독립) & .099 & 1.813 & .071 & \multirow{2}{*}{$80.134^{* * *}$} & \multirow{2}{*}{.348} & \\
\hline & 3단계(매개) & .532 & $9.686^{* * *}$ & .000 & & & \\
\hline \multicolumn{8}{|c|}{$* * \mathrm{p}<.01, * * * \mathrm{p}<.001$} \\
\hline
\end{tabular}

[표 8] 라이브커머스 특성과 구매의도 간의 관계에서 쾌락적 가치의 매개효과

[Table 8] The Intermediate Effect of Hedonic Value in the Relationship between Live Commerce Characteristics and Purchase Intent

\begin{tabular}{|c|c|c|c|c|c|c|c|}
\hline 구분 & 단계 & $\beta$ & $\mathrm{t}$ & $\mathrm{p}$ & $\mathrm{F}$ & $\mathrm{R}^{2}$ & 채택유무 \\
\hline \multirow{4}{*}{ 정보성 } & 1단계 & .499 & $10.000 * * *$ & .000 & $99.996^{* * *}$ & .249 & \multirow{4}{*}{ 부분매개 } \\
\hline & 2단계 & .395 & $7.461 * * *$ & .000 & $55.670^{* * *}$ & .156 & \\
\hline & 3단계(독립) & .131 & $2.474 *$ & .014 & \multirow{2}{*}{$86.389^{* * *}$} & \multirow{2}{*}{.365} & \\
\hline & 3단계(매개) & .528 & $9.949 * * *$ & .000 & & & \\
\hline \multirow{4}{*}{ 오락성 } & 1단계 & .746 & $19.434 * * *$ & .000 & $377.677 * * *$ & .556 & \multirow{4}{*}{ 완전매개 } \\
\hline & 2단계 & .482 & $9.544 * * *$ & .000 & $91.086^{* * *}$ & .232 & \\
\hline & 3단계(독립) & .088 & 1.267 & .206 & \multirow{2}{*}{$82.901 * * *$} & \multirow{2}{*}{.356} & \\
\hline & 3단계(매개) & .528 & $7.589 * * *$ & .000 & & & \\
\hline \multirow{4}{*}{ 경제성 } & 1단계 & .524 & $10.674 * * *$ & .000 & $113.938^{* * *}$ & .275 & \multirow{4}{*}{ 완전매개 } \\
\hline & 2단계 & .380 & $7.126^{* * *}$ & .000 & $50.780^{* * *}$ & .144 & \\
\hline & 3단계(독립) & .095 & 1.748 & .081 & \multirow{2}{*}{$84.222 * * *$} & \multirow{2}{*}{.359} & \\
\hline & 3단계(매개) & .544 & $10.024 * * *$ & .000 & & & \\
\hline \multicolumn{8}{|c|}{${ }^{*} \mathrm{p} p<.01, * * * \mathrm{p}<.001$} \\
\hline
\end{tabular}

\subsection{6 인플루언서 특성과 구매의도와 관계에서 지각된 가치의 매개효과}

인플루언서 특성이 구매의도와 관계에서 실용적 가치의 매개효과를 분석한 결과, 전문성, 매력성, 신뢰성, 상호작용성은 1단계 ( $\mathrm{p}<.001), 2$ 단계 $(\mathrm{p}<.001)$ 매개조건을 충족하였고, 3 단계에서 매력성, 신뢰성, 상호작용성은 모두 부분매개하는 것으로 나타났다. 쾌락적 가치의 매개효과를 분석한 결과에서도 1 단계 $(\mathrm{p}<.001), 2$ 단계 $(\mathrm{p}<.001)$ 매개조건을 충족하였고, 3 단계에서 매력성, 신뢰성, 상호작용성은 모두 부분매개하는 것으로 나타났다. 인플루언서 특성은 모두 부분매개했다고 할 수 있다.

[표 9] 인플루언서 특성과 구매의도 간의 관계에서 실용적 가치의 매개효과

[Table 9] The Intermediate Effect of Practical Value in the Relationship between Influencer Characteristics 
and Purchase Intention

\begin{tabular}{|c|c|c|c|c|c|c|c|}
\hline 구분 & 단계 & $\beta$ & $\mathrm{t}$ & $\mathrm{p}$ & $\mathrm{F}$ & $\mathrm{R}^{2}$ & 채택유무 \\
\hline \multirow{4}{*}{ 전문성 } & 1단계 & .535 & $10.973 * * *$ & .000 & $120.413 * * *$ & .286 & \multirow{4}{*}{ 부분매개 } \\
\hline & 2단계 & .395 & $7.451^{* * *}$ & .000 & $55.514^{* * *}$ & .156 & \\
\hline & 3단계(독립) & .115 & $2.096^{*}$ & .037 & \multirow{2}{*}{$80.975^{* * *}$} & \multirow{2}{*}{.351} & \\
\hline & 3단계(매개) & .522 & $9.488 * * *$ & .000 & & & \\
\hline \multirow{4}{*}{ 매력성 } & 1단계 & .423 & $8.095 * * *$ & .000 & $65.525^{* * *}$ & .179 & \multirow{4}{*}{ 부분매개 } \\
\hline & 2단계 & .372 & $6.956^{* * *}$ & .000 & $48.391 * * *$ & .138 & \\
\hline & 3단계(독립) & .152 & $2.992 * *$ & .003 & \multirow{2}{*}{$84.435^{* * *}$} & \multirow{2}{*}{.360} & \\
\hline & 3단계(매개) & .520 & $10.195^{* * *}$ & .000 & & & \\
\hline \multirow{4}{*}{ 신뢰성 } & 1단계 & .491 & $9.769 * * *$ & .000 & $95.437 * * *$ & .241 & \multirow{4}{*}{ 부분매개 } \\
\hline & 2단계 & .421 & $8.044 * * *$ & .000 & $64.698^{* * *}$ & .177 & \\
\hline & 3단계(독립) & .177 & $3.344 * *$ & .001 & \multirow{2}{*}{$86.124 * * *$} & \multirow{2}{*}{.365} & \\
\hline & 3단계(매개) & .497 & $9.418^{* * *}$ & .000 & & & \\
\hline \multirow{4}{*}{$\begin{array}{l}\text { 상호 } \\
\text { 작용성 }\end{array}$} & 1단계 & .484 & $9.602 * * *$ & .000 & $92.201 * * *$ & .234 & \multirow{4}{*}{ 부분매개 } \\
\hline & 2단계 & .394 & $7.436^{* * *}$ & .000 & $55.298^{* * *}$ & .155 & \\
\hline & 3단계(독립) & .145 & $2.745^{* *}$ & .006 & \multirow{2}{*}{$83.357^{* * *}$} & \multirow{2}{*}{.357} & \\
\hline & 3단계(매개) & .514 & $9.710^{* * *}$ & .000 & & & \\
\hline
\end{tabular}

[표 10] 인플루언서 특성과 구매의도 간 쾌락적 가치의 매개효과

[Table 10] The Intermediate Effect of Hedonic Value in the Relationship between Influencer Characteristics and Purchase Intention

\begin{tabular}{|c|c|c|c|c|c|c|c|}
\hline 구분 & 단계 & $\beta$ & $\mathrm{t}$ & $\mathrm{p}$ & $\mathrm{F}$ & $\mathrm{R}^{2}$ & 채택유무 \\
\hline \multirow{4}{*}{ 전문성 } & 1단계 & .419 & $7.998 * * *$ & .000 & $63.965^{* * *}$ & .175 & \multirow{4}{*}{ 부분매개 } \\
\hline & 2단계 & .395 & $7.451 * * *$ & .000 & $55.514 * * *$ & .156 & \\
\hline & 3단계(독립) & .177 & $3.533 * * *$ & .000 & \multirow{2}{*}{$91.300^{* * *}$} & \multirow{2}{*}{.378} & \\
\hline & 3단계(매개) & .520 & $10.366^{* * *}$ & .000 & & & \\
\hline \multirow{4}{*}{ 매력성 } & 1단계 & .449 & $8.707 * * *$ & .000 & $75.813^{* * *}$ & .201 & \multirow{4}{*}{ 부분매개 } \\
\hline & 2단계 & .372 & $6.956^{* * *}$ & .000 & $48.391 * * *$ & .138 & \\
\hline & 3단계(독립) & .133 & $2.577 *$ & .010 & \multirow{2}{*}{$86.791 * * *$} & \multirow{2}{*}{.367} & \\
\hline & 3단계(매개) & .534 & $10.392 * * *$ & .000 & & & \\
\hline \multirow{4}{*}{ 신뢰성 } & 1단계 & .489 & $9.714 * * *$ & .000 & $94.355^{* * *}$ & .239 & \multirow{4}{*}{ 부분매개 } \\
\hline & 2단계 & .421 & $8.044 * * *$ & .000 & $64.698 * * *$ & .177 & \\
\hline & 3단계(독립) & .171 & $3.278 * *$ & .001 & \multirow{2}{*}{$89.960 * * *$} & \multirow{2}{*}{.375} & \\
\hline & 3단계(매개) & .510 & $9.748 * * *$ & .000 & & & \\
\hline \multirow{4}{*}{$\begin{array}{c}\text { 상호 } \\
\text { 작용성 }\end{array}$} & 1단계 & .515 & $10.416^{* * *}$ & .000 & $108.495 * * *$ & .265 & \multirow{4}{*}{ 부분매개 } \\
\hline & 2단계 & .394 & $7.436^{* * *}$ & .000 & $55.298 * * *$ & .155 & \\
\hline & 3단계(독립) & .120 & $2.237^{*}$ & .026 & \multirow{2}{*}{$85.524 * * *$} & \multirow{2}{*}{.363} & \\
\hline & 3단계(매개) & .532 & $9.897 * * *$ & .000 & & & \\
\hline \multicolumn{8}{|c|}{$* * \mathrm{p}<.01, * * * \mathrm{p}<.001$} \\
\hline
\end{tabular}




\subsection{7 라이브커머스 특성과 구매의도와 관계에서 자아일치성의 조절효과}

라이브커머스 특성이 구매의도와 관계에서 실제적 자아의 조절효과를 알아보기 위하여 위계적 회귀분석을 실시한 결과, 실제적 자아는 라이브커머스특성의 하위요인별 경제성이 구매의도 간의 관계를 조절하고 있었다. 이상적 자아는 정보성이 구매의도 간의 관계를 조절하는 것으로 나타났다.

[표 11] 실제적 자아일치성의 조절효과

[Table 11] The Moderating Effect of Actual Self-consistency

\begin{tabular}{|c|c|c|c|c|c|c|c|c|c|}
\hline \multirow{2}{*}{ 변수 } & \multicolumn{3}{|c|}{ 모델 I } & \multicolumn{3}{|c|}{ 모델II } & \multicolumn{3}{|c|}{ 모델III } \\
\hline & 변수 $\beta$ & $\mathrm{t}$ & $\mathrm{p}$ & $\beta$ & $\mathrm{t}$ & $\mathrm{p}$ & $\beta$ & $\mathrm{t}$ & $\mathrm{p}$ \\
\hline 정보성(A) & .175 & $3.011 * *$ & .003 & .107 & 1.941 & .053 & .132 & $2.397 *$ & .017 \\
\hline 오락성(B) & .326 & $5.345 * * *$ & .000 & .224 & $3.789 * * *$ & .000 & .213 & $3.711 * * *$ & .000 \\
\hline 경제성(C) & .137 & $2.321^{*}$ & .021 & .019 & .330 & .742 & .031 & .545 & .586 \\
\hline 실제적 자아(M1) & & & & .385 & $6.649 * * *$ & .000 & .360 & $6.415 * * *$ & .000 \\
\hline$(\mathrm{A}) \times(\mathrm{M})$ & & & & & & & .089 & 1.324 & .187 \\
\hline$(\mathrm{B}) \times(\mathrm{M})$ & & & & & & & -.070 & -1.073 & .284 \\
\hline$(\mathrm{C}) \times(\mathrm{M})$ & & & & & & & .216 & $3.381 * *$ & .001 \\
\hline F-value & \multicolumn{3}{|c|}{$38.436^{* * *}$} & \multicolumn{3}{|c|}{$44.047^{* * *}$} & \multicolumn{3}{|c|}{$31.491 * * *$} \\
\hline$\Delta F$-value & \multicolumn{3}{|c|}{-} & \multicolumn{3}{|c|}{$44.215^{* * *}$} & \multicolumn{3}{|c|}{$44.215^{* * *}$} \\
\hline $\mathrm{R}^{2}$ & \multicolumn{3}{|c|}{.278} & \multicolumn{3}{|c|}{.372} & \multicolumn{3}{|c|}{.428} \\
\hline$\Delta \mathrm{R}^{2}$ & \multicolumn{3}{|c|}{-} & \multicolumn{3}{|c|}{.094} & \multicolumn{3}{|c|}{.056} \\
\hline \multicolumn{10}{|c|}{$* \mathrm{p}<.05, * * \mathrm{p}<.01, * * * \mathrm{p}<.001$} \\
\hline
\end{tabular}

[표 12] 이상적 자아일치성의 조절효과

[Table 12] The Moderating Effect of Ideal Self-consistency

\begin{tabular}{|c|c|c|c|c|c|c|c|c|c|}
\hline \multirow{2}{*}{ 변수 } & \multicolumn{3}{|c|}{ 모델 I } & \multicolumn{3}{|c|}{ 모델II } & \multicolumn{3}{|c|}{ 모델III } \\
\hline & $\beta$ & $\mathrm{t}$ & $\mathrm{p}$ & $\beta$ & $\mathrm{t}$ & $\mathrm{p}$ & $\beta$ & $\mathrm{t}$ & $\mathrm{p}$ \\
\hline 정보성(A) & .175 & $3.011^{* *}$ & .003 & .061 & 1.035 & .301 & .126 & $2.163^{*}$ & .031 \\
\hline 오락성(B) & .326 & $5.345^{* * *}$ & .000 & .211 & $3.447 * *$ & .001 & .178 & $3.031 * *$ & .003 \\
\hline 경제성(C) & \multirow[t]{2}{*}{.137} & \multirow[t]{2}{*}{$2.321 *$} & \multirow[t]{2}{*}{.021} & .107 & 1.897 & .059 & .114 & $2.115^{*}$ & .035 \\
\hline 이상적 자아(M2) & & & & .344 & $5.737 * * *$ & .000 & .338 & $5.790^{* * *}$ & .000 \\
\hline$(\mathrm{A}) \times(\mathrm{M})$ & & & & & & & .246 & $3.841 * * *$ & .000 \\
\hline$(\mathrm{B}) \times(\mathrm{M})$ & & & & & & & -.064 & -.951 & .342 \\
\hline$(\mathrm{C}) \times(\mathrm{M})$ & & & & & & & .098 & 1.655 & .099 \\
\hline F-value & \multicolumn{3}{|c|}{$38.436^{* * *}$} & \multicolumn{3}{|c|}{$40.131^{* * *}$} & \multicolumn{3}{|c|}{$30.414 * * *$} \\
\hline$\Delta \mathrm{F}$-value & \multicolumn{3}{|c|}{-} & \multicolumn{3}{|c|}{$32.910^{* * *}$} & \multicolumn{3}{|c|}{$11.696^{* * *}$} \\
\hline $\mathrm{R}^{2}$ & \multicolumn{3}{|c|}{.278} & \multicolumn{3}{|c|}{.350} & \multicolumn{3}{|c|}{.419} \\
\hline$\Delta \mathrm{R}^{2}$ & \multicolumn{3}{|c|}{-} & \multicolumn{3}{|c|}{.072} & \multicolumn{3}{|c|}{.069} \\
\hline
\end{tabular}




\subsection{8 인플루언서 특성과 구매의도와 관계에서 자아일치성의 조절효과}

인플루언서 특성이 구매의도와 관계에서 실제적 자아의 조절효과를 알아보기 위하여 위계적 회귀분석을 실시한 결과, 실제적 자아는 인플루언서 특성의 하위요인별 전문성이 구매의도 간의 관계를 조절하고 있었다. 이상적 자아는 매력성이 구매의도 간의 관계를 조절하는 것으로 나타났다.

[표 13] 실제적 자아일치성의 조절효과

[Table 13] The Moderating Effect of Actual Self-consistency

\begin{tabular}{|c|c|c|c|c|c|c|c|c|c|}
\hline \multirow{2}{*}{ 변수 } & \multicolumn{3}{|c|}{ 모델 I } & \multicolumn{3}{|c|}{ 모델II } & \multicolumn{3}{|c|}{ 모델III } \\
\hline & 변수 $\beta$ & $\mathrm{t}$ & $\mathrm{p}$ & $\beta$ & $\mathrm{t}$ & $\mathrm{p}$ & $\beta$ & $\mathrm{t}$ & $\mathrm{p}$ \\
\hline 전문성(A) & .139 & $2.117^{*}$ & .035 & .058 & .933 & .352 & .101 & 1.662 & .098 \\
\hline 매력성(B) & .143 & $2.333^{*}$ & .020 & .113 & 1.968 & .050 & .086 & 1.496 & .136 \\
\hline 신뢰성(C) & .192 & $2.887 * *$ & .004 & .057 & .869 & .385 & .015 & .232 & .817 \\
\hline 상호작용성(D) & .152 & $2.375^{*}$ & .018 & .076 & 1.252 & .211 & .090 & 1.509 & .132 \\
\hline 실제적 자아(M1) & & & & .408 & $6.645 * * *$ & .000 & .431 & $7.133 * * *$ & .000 \\
\hline$(\mathrm{A}) \times(\mathrm{M})$ & & & & & & & .183 & $2.391 *$ & .017 \\
\hline$(\mathrm{B}) \times(\mathrm{M})$ & & & & & & & -.028 & -.474 & .636 \\
\hline$(\mathrm{C}) \times(\mathrm{M})$ & & & & & & & .067 & .900 & .369 \\
\hline$(\mathrm{D}) \times(\mathrm{M})$ & & & & & & & .048 & .721 & .471 \\
\hline F-value & \multicolumn{3}{|c|}{$24.678 * * *$} & \multicolumn{3}{|c|}{$31.434 * * *$} & \multicolumn{3}{|c|}{$22.643 * * *$} \\
\hline$\Delta \mathrm{F}$-value & \multicolumn{3}{|c|}{-} & \multicolumn{3}{|c|}{$44.162 * * *$} & \multicolumn{3}{|c|}{$7.966^{* * *}$} \\
\hline $\mathrm{R}^{2}$ & \multicolumn{3}{|c|}{.249} & \multicolumn{3}{|c|}{.346} & \multicolumn{3}{|c|}{.410} \\
\hline$\Delta \mathrm{R}^{2}$ & \multicolumn{3}{|c|}{-} & \multicolumn{3}{|c|}{.097} & \multicolumn{3}{|c|}{.064} \\
\hline \multicolumn{10}{|c|}{$* \mathrm{p}<.05, * * \mathrm{p}<.01, * * * \mathrm{p}<.001$} \\
\hline
\end{tabular}

[표 14] 이상적 자아일치성의 조절효과

[Table 14] The Moderating Effect of Ideal Self-consistency

\begin{tabular}{|c|c|c|c|c|c|c|c|c|c|}
\hline \multirow{2}{*}{ 변수 } & \multicolumn{3}{|c|}{ 모델 I } & \multicolumn{3}{|c|}{ 모델II } & \multicolumn{3}{|c|}{ 모델III } \\
\hline & 변수 $\beta$ & $\mathrm{t}$ & $\mathrm{p}$ & $\beta$ & $\mathrm{t}$ & $\mathrm{p}$ & $\beta$ & $\mathrm{t}$ & $\mathrm{p}$ \\
\hline 전문성(A) & .139 & $2.117^{*}$ & .035 & .093 & 1.511 & .132 & .121 & $2.027 *$ & .044 \\
\hline 매력성(B) & .143 & $2.333^{*}$ & .020 & .061 & 1.052 & .294 & .085 & 1.441 & .151 \\
\hline 신뢰성(C) & .192 & $2.887^{* *}$ & .004 & .159 & $2.552 *$ & .011 & .137 & $2.182 *$ & .030 \\
\hline 상호작용성(D) & .152 & $2.375^{*}$ & .018 & .043 & .688 & .492 & .050 & .824 & .411 \\
\hline 이상적 자아(M2) & & & & .381 & $6.645 * * *$ & .000 & .377 & $6.720 * * *$ & .000 \\
\hline$(\mathrm{A}) \times(\mathrm{M})$ & & & & & & & .051 & .685 & .494 \\
\hline$(\mathrm{B}) \times(\mathrm{M})$ & & & & & & & .126 & $2.141^{*}$ & .033 \\
\hline$(\mathrm{C}) \times(\mathrm{M})$ & & & & & & & .056 & .747 & .456 \\
\hline (D) $\times(\mathrm{M})$ & & & & & & & .074 & 1.150 & .251 \\
\hline F-value & \multicolumn{3}{|c|}{$24.678^{* * *}$} & \multicolumn{3}{|c|}{$31.548^{* * *}$} & \multicolumn{3}{|c|}{$22.610^{* * *}$} \\
\hline$\Delta \mathrm{F}$-value & \multicolumn{3}{|c|}{-} & \multicolumn{3}{|c|}{$44.589 * * *$} & \multicolumn{3}{|c|}{$7.817 * * *$} \\
\hline $\mathrm{R}^{2}$ & \multicolumn{3}{|c|}{.249} & \multicolumn{3}{|c|}{.347} & \multicolumn{3}{|c|}{.410} \\
\hline
\end{tabular}




\begin{tabular}{|c|r|r|r|}
\hline$\Delta \mathrm{R}^{2}$ & - & .098 & .063 \\
\hline \multicolumn{5}{|c|}{${ }^{*} \mathrm{p}<.05, * * \mathrm{p}<.01, * * * \mathrm{p}<.001$} \\
\hline
\end{tabular}

\subsection{9 연구모형에 따른 가설 검증 결과요약}

본 연구의 가설에 따른 검증 결과는 다음과 같다. H1 라이브커머스 특성이 구매의도에 미치는 영향과, $\mathrm{H} 2$ 인플루언서의 특성이 구매의도에 영향을 미칠 것이라는 가설은 채택되었다. $\mathrm{H} 3$ 지각된 가치가 구매의도에 영향을 미칠 것이다라는 가설과 $\mathrm{H} 4$ 라이브커머스 특성이 지각된 가치에 영향을 미칠 것이라는 가설도 채택되었다. 그러나 $\mathrm{H} 5$ 인플루언서 특성이 지각된 가치에 영향을 미칠 것이라는 가설은 부분 채택되었다. H6(H6-1, H6-2) 지각된 가치(실용적 가치, 쾌락적 가치)는 라이브커머스 특성, 인플루언서 특성과 구매의도간의 관계를 매개할 것이라는 가설은 채택되었다. H7(H7-1, H7-2) 자아일치성(실제적 자아, 이상적 자아)은 라이브커머스 특성, 인플루언서 특성과 구매의도간의 관계를 조절할 것이라는 가설은 부분채택되었다. 이상의 가설검증 결과를 요약하면 [Fig. 2]와 같다.

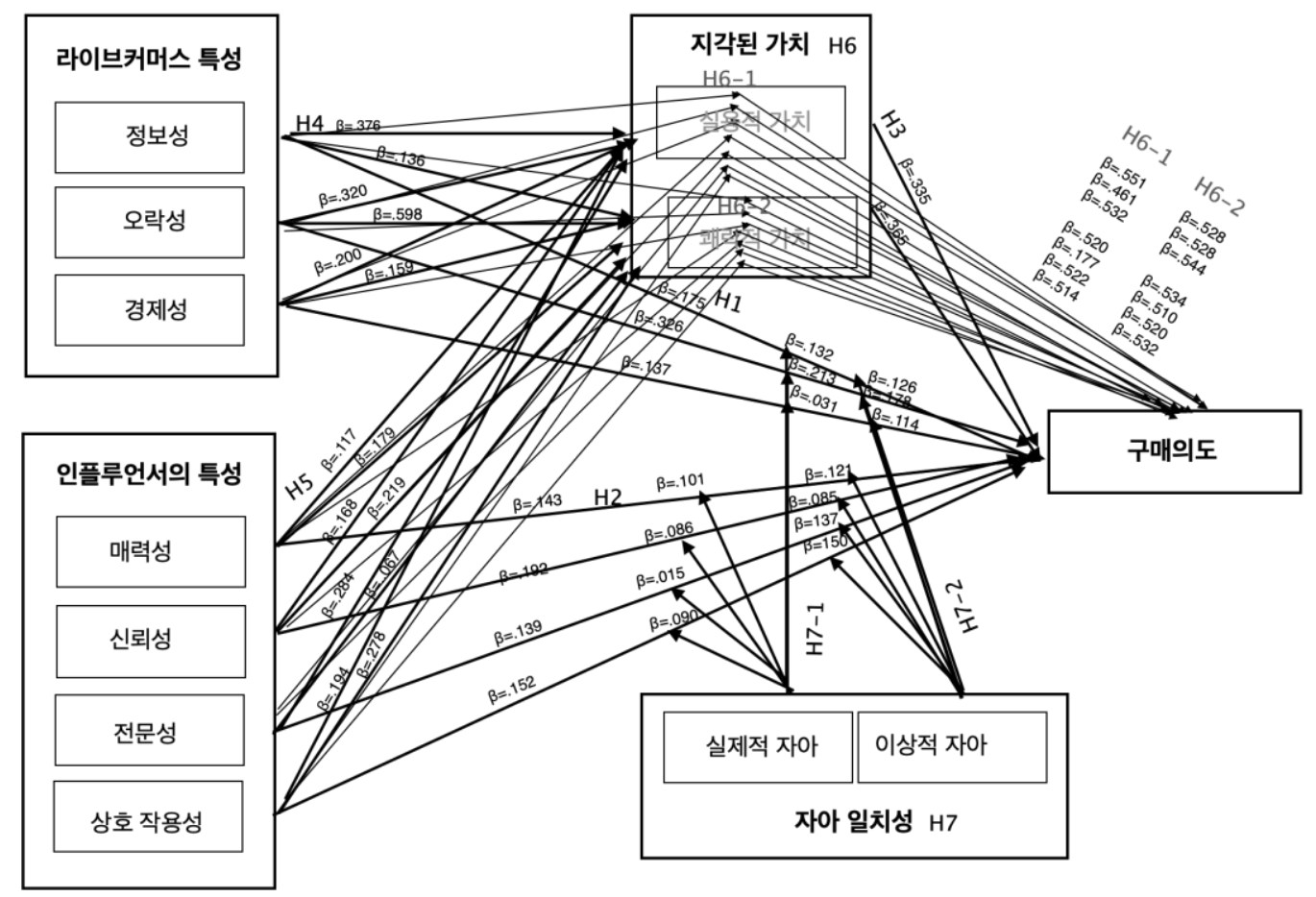

[그림 2] 연구모형에 따른 결과

[Fig. 2] Research Mode Analysis Results

\section{5. 결론}

\section{1 연구결과의 요약 및 시사점}

본 연구는 COVID-19 이후, 라이브커머스의 성장과 소비자의 구매행태에 주목하여, 라이브커머스의 특성과 인플루언서 특성에 따른 소비자의 구매의도 및 지각된 가치와 
구매의도 요인간에 매개효과와, 자아일치성을 조절효과로 검증하였다.

첫째, 라이브커머스 특성과 인플루언서 특성이 구매의도에 미치는 영향에 관한 연구결과, 라이브커머스의 특성은 오락성, 정보성, 경제성 순으로 구매의도와 유의미한 상관관계를 나타냈다. 인플루언서의 특성은 신뢰성, 상호작용성, 매력성, 전문성 순으로 구매의도에 영향을 미쳤다. 온라인 쇼핑에 익숙한 소비자들은 제품과 서비스를 구매함에 있어 이미 충분한 정보, 지식을 가지고 있으며 이들의 소비 가치체계는 상대적인 것에서 절대적인 것으로 변하고 있다. 따라서, 라이브커머스 채널은 고객의 시간점유율을 높이기 위한 엔터테인먼트 마케팅 전략의 필요성을 제기된다. 또한, 인플루언서는 라이브커머스 채널 내에서 중요한 매개 역할을 하기 때문에 흥미롭고 날 것의 실재적 정보를 제공하여 쇼핑에 대한 기대와 고객경험, 쇼핑 자체를 논리적이고 목표달성 차원으로 달성할 수 있도록 해야 할 것이다.

둘째, 지각된 가치가 구매의도에 미치는 영향은 유의미한 결과를 도출했다. 라이브커머스의 특성과 인플루언서의 특성이 지각된 가치에 미치는 영향에서, 라이브커머스의 정보성, 오락성, 경제성은 실용적 가치에 영향을 주었고, 오락성, 경제성, 정보성은 쾌락적 가치에 유의미한 영향을 미쳤다. 인플루언서의 전문성, 상호작용성, 신뢰성, 매력성은 실용적 가치에 영향을 주었으며, 상호작용성, 신뢰성, 매력성은 쾌락적 가치에 통계적으로 유의미했다. COVID-19 이후 소비가치의 변화는 실용적 가치와 쾌락적 가치를 동시에 추구한다고 볼 수 있다[20]. 또한, 상호커뮤니케이션 방식은 정보 콘텐츠로서의 소비 가치와 문제해결 관점의 전문성을 요구하며, 즉각적이고 감각적인 반응, 자신의 맞춤 서비스를 제공받기를 원한다고 해석 할 수 있다. 따라서, 각 채널은 일회성이 아니라 다른 정보의 유익성 차원과 사회적 신뢰성 차원에서, 심리적 거리를 좁히고 소비자과 함께 만드는 팬-쉽 전략이 필요하다고 볼 수 있다.

셋째, 지각된 가치의 매개 효과를 검증한 결과, 라이브커머스 정보성, 경제성은 실용적 가치에 완전매개했고, 오락성은 부분 매개했다. 쾌락적 가치는 오락성, 경제성을 완전 매개했으며, 정보성은 부분매개했다. 인플루언서 전문성, 매력성, 신뢰성, 상호작용성은 실용적 가치와 쾌락적 가치를 모두 부분매개했다. 이는 코로나로 인한 제한된 외부 세계의 정보와 사회적 관계욕구를 인플루언서와의 감각적 경험이나 즐거움, 지적 성취감 등을 통해 사회적, 심리적 충족시키려하기 때문으로 해석된다.

넷째, 자아일치성에 따른 조절효과에서 실제적 자아는 라이브커머스의 경제성과 인플루언서 전문성이 구매의도를 조절하고 있었다. 이상적 자아는 라이브커머스의 정보성과 인플루언서의 매력성이 구매의도 간의 관계를 조절했다. 실제적 자아는 정확한 목적을 가지고 쇼핑하기 때문에, 현실적인 경제성과 정보에 대한 전문성이 중요한 요인이라고 볼 수 있으며, 이상적 자아는 자기해석이 비슷한 인플루언서에게 상대적으로 긍정적으로 평가하며, 롤모델과의 비교를 통해 이상적 가치를 소비하기 때문에 소비의 상징적 의미체계를 전달하는 것이 중요하다고 볼 수 있다. 코로나 이후 소비자들의 소비행동 변화는 개인의 취향을 적극적으로 표현함으로써 실존적 가치를 제고하고, 궁극적으로는 이상적이고 자기충족적 소비행태를 보인다고 해석할 수 있다.

\section{2 연구의 한계점 및 향후 연구방안}

최근 소비시장은 디지털 트랜스포메이션을 화두로 비즈니스모델에 많은 변화를 보이고 있다. 따라서 본 연구는 국내 초기 라이브커머스에 대한 적절한 시의적 연구라고 말할 
수 있다. 그러나 국내 라이브커머스 초기시장의 선행연구가 부족하였고, 연구대상인 네이버가 각 라이브커머스의 대표적 특성을 나타낸다고 말할 수 없다. 조사대상은 일반인을 대상으로 진행하여 라이브커머스 주요 타겟의 구매의도를 분석하지 못했다. 방법론에서도 매개효과와 조절효과의 도구적 특성에 따른 다양한 변수를 배제할 수 없다는 한계점도 있다. 최근 라이브커머스의 성장은 상호작용, 개인화된 추천시스템 알고리즘 등의 발전으로 괄목할 만한 성장을 하고 있다. 이에 후속 연구로, 빅데이터와 인터페이스를 중심으로 새로운 기술수용에 관한 소비자 태도와, 소비자 인지적 위험인식 및 신뢰에 관한 실증적 연구를 제언하는 바이다. 또한, 최근 소비지형이 인공지능, AR, $\mathrm{VR}$ 기술을 접목한 메타버스 가상세계로 이동하고 있음에 따라 가상 플랫폼 특성에 따른 가상 소비문화 연구를 후속으로 진행한다면, 미래 소비자의 라이프스타일 및 소비가치에 대해 유의미한 연구 결과를 얻을 수 있을 것이다.

\section{Reference}

[1] http://www.sisaweek.com/news/articleView.html?idxno=140101, Dec 14 (2020)

[2] Oh Rin-a, Korea Live Commerce Market Analysis and Forecast, eBest Investment \& Securities, pp.13-14, (2020)

[3] Lee Chae-hyun, A Study on the Effect of Mobile Live Commerce Characteristics on the Intention to Purchase, Soongsil University Graduate School of Business, Ph.D dissertation (2019)

[4] Cui Yiling, Effects of Self-consistency on Purchase Intention and oral effects: Seoul National University Graduate School, Ph.D dissertation, (2019)

[5] Song Seo-seol, The Effect of Interaction and Relationship Quality on Chinese Consumers' Purchase Intention in Live Streaming Social Commerce: Mediating effects of social reality and immersion and controlling social support, SuwonUniversity Graduate School. Ph.D dissertation, (2020).

[6] S. T. Biucky, S. R. Harandi, N. Abdolvand, The effects of perceived risk on social commerce adoption based on TAM model, International Journal of- 100 -Electronic Commerce Studies, (2017), Vol.8, No.2, pp.173-196. DOI:10.7903/ijecs.1538

[7] Jang Yi-nyeong, Park Hyun-jung, Factors Influencing the Consumer Attitude toward Product Purchasing Related to Chinese Personal Internet Broadcasting Wang Hong, The Journal of the Korea Contents Association, (2018), Vol.18, No.10, pp.1-10. DOI: 10.5392/JKCA.2018.18.10.001

[8] Kang Kyung-hee, A Study on the Influence of SNS Characteristics on Brand Attitude by Collective Intelligence: Focusing on Facebook, Hongik University Graduate School of Industrial Art. Master's Thesis (2012)

[9] Wen, Jiachen, Factors affecting Chinese consumers' intention to buy live streaming commerce, Ewha Womans University Graduate School. Master's Thesis, (2020)

[10] Kim Jong-ryum, Jun Jong-woo, Measuring Attractiveness of Celebrities, Ewha Journal of Social Sciences, (2016), Vol.32, No.2, pp.73-112, DOI: 10.16935/ejss.2016.32.2.003

[11] S.-C.Wang, E. Sy, K. Fang, The Post-Adoption Behavior of Online Knowledge Community: Decomposing Customer Value, Journal of Computer Information Systems, (2015), Vol.51, No.2, pp.60-70, DOI: $10.1080 / 08874417.2010 .11645469$

[12] Lee Ho-jin, Perceived shopping value, sales promotion type and control focus of men's cosmetics on goodwill and purchase intention: focusing on social commerce, Sungkyunkwan University Graduate School, Master's Thesis, (2017)

[13] Wang Hye-min, Lee Kyung-tak, Kim Na-yeon, The Effect of Technology Behavior Induction on Live Streaming Commerce's Purchase Intention, Proceeding of the 22nd Convergence Conference of the Korean Business Association 2020, (2020), August 17; Seoul, Korea 
[14] Kim Young-in, A Study on the Influence of Product Personality on Consumer's Self-image Consensus, Product Preference, and Purchase Intention, Kyunghee University Graduate School, Master's Thesis, (2012)

[15] Lee Sang-mi, A Study on the Selection Behavior of Tourist Destinations Based on Self-Consistency and Functional Consistency, Dong-A University Graduate School, Master's Thesis, (2009)

[16] Kim Jin Kyung, Research on the service quality and the clothing purchase behavior through Internet Shopping Mall, Ewha Womans University, Master's thesis, (2008)

[17] Lee Wook, Lee Gun Bin, Ji Myung Geun, Ahn Jong Chang, A Study on the factors of SNS information influencing consumers' purchasing intention: focusing on Chinese Weibo, Journal of Korea Academia-Industrial cooperation Society, (2017), Vol.18, No.7, pp.92-101. DOI: 10.5762/KAIS.2017.18.7.92

[18] Chae Seo-il, 3rd edition of the Social Science Research Methodology, B\&M Books, (2004)

[19] Kim Kye-soo, Structural Equation Model Analysis, Han Narae Academy, (2011)

[20] Seo Kyung-hwa, Choi Won-Sik, Lee Soo-Bum, A Study on the Influence of the Selective Attributes of Home Meal Replacement on Perceived Utilitarian Value and Repurchase Intention: Focus on Consumers of Large Discount and Department Stores, The East Asian Society of Dietary Life, (2011), Vol.21, No.6, pp.934-947. UCI: G704001333.2011.21.6.003 